\title{
Polymeric Iodophors: Preparation, Properties, and Biomedical Applications
}

\author{
D. N. Makhayeva ${ }^{a}$, G. S. Irmukhametova ${ }^{a, *}$, and V. V. Khutoryanskiy ${ }^{b, * *}$ \\ ${ }^{a}$ Al-Farabi Kazakh National University, Almaty, 050040, Kazakhstan \\ ${ }^{b}$ University of Reading, Whiteknights, Reading, Berkshire, RG6 6AH United Kingdom \\ *e-mail: galiya.irm@gmail.com \\ **e-mail:v.khutoryanskiy@reading.ac.uk
}

Received May 8, 2020; revised August 19, 2020; accepted September 28, 2020

\begin{abstract}
The review summarizes the data on the main chemical and physiological properties of iodine and its capability of complexation with natural and synthetic polymers. Iodine is the best known antiseptic used to prevent and treat microbial infections. Its unique capability of complexation with certain polymers opens wide opportunities for targeted and prolonged delivery to target organs. Polymeric complexes with iodine have another color, other morphology, a higher electrical conductivity, and higher biological activity as compared with initial polymers. The formation of $\mathrm{I}_{3}^{-}$and $\mathrm{I}_{5}^{-}$ions is associated with iodine-polymer complexation. Iodine-containing biocompatible adhesive controlledrelease formulations are designed as part of research into iodine-polymer complexes. The field is promising in terms of treating certain diseases because tolerance to iodine compounds does not usually develop in microbial cells.
\end{abstract}

Keywords: iodophors, iodine-polymer complexes, biological activity, antimicrobial activity, antiseptics

DOI: $10.1134 / \mathrm{S} 2079978020010033$

\section{Contents}

1. Introduction

2. Iodine: Main Chemical Properties

3. Iodophor Preparation: Main Methods and Complexation Mechanism

4. Applications of Polymeric Iodophors

\section{INTRODUCTION}

Iodine has long been used as an antiseptic to prevent and treat a broad range of infections. However, its use was limited by several undesirable factors, such as irritation, an increase in sensitivity, staining of biological and artificial surfaces, a low solubility in water, and a high vapor pressure. In the early 1950s, a "conquest" of iodine started with investigating its complexation with certain polymers to yield compounds of a new class, which are known as iodophors [1].

Iodophors are chemical complexes that contain a mixture of molecular iodine, iodide ions, and a solubilizing agent [2]. Natural and synthetic water-soluble polymers and nonionic surfactants are broadly used as solubilizing agents. Complexation with polymeric carriers increases the solubility of molecular iodine, facilitates its prolonged release [3], and decreases the steady-state concentration of free iodine [4].

Iodine possesses antimicrobial and antiseptic properties. While antibiotics are localized in a particular site, iodine simultaneously affects all structures of a microbial cell. Iodine binds with proteins to cause their denaturation via several mechanisms, e.g., by oxidizing the $\mathrm{SH}$ groups in cysteine and methionine residues and preventing hydrogen bonding between the amino groups of arginines and histidines and the phenol groups of tyrosines. The changes affect the structure and functions of microbial cells. Iodine is additionally capable of binding with fatty acids at $\mathrm{C}-\mathrm{C}$ bonds and certain nucleotides (adenine, cytosine, and guanine), thus altering the structures of nucleic acids and the entire cell membrane in bacteria. Membranes and the cytoplasm are thus quickly destroyed in cells exposed to iodine [1]. For example, the effects 


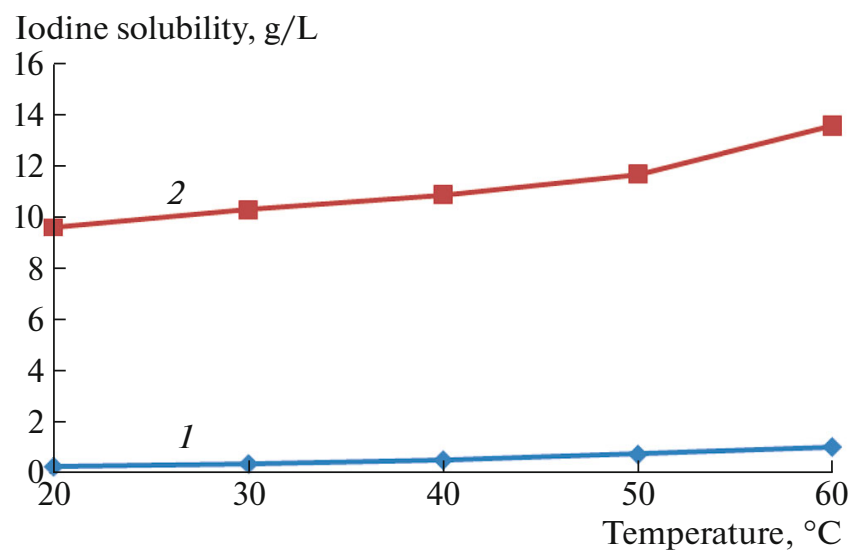

Fig. 1. Temperature dependences of iodine solubility in (1) water and (2) $0.1 \mathrm{~g} / \mathrm{L}$ potassium iodide. Data to plot the dependences were taken from [4].

of the iodophor polyvinylpyrrolidone (PVP)-iodine were studied in bacterial cells by electron microscopy and biochemical methods and were found to include rapid separation of the cytoplasm, nucleotide coagulation, and loss of enzymatic activities. Cells were not degraded completely, but pores arose in the cell wall to cause leakage of cell components [5].

The broad range of iodophor applications makes it possible to design various iodine-polymer formulations, such as solutions, ointments, foaming creams, films, mucoadhesive tablets, etc. Iodophors are stable upon long-term storage, and their side effects are extremely rare [6].

The review considers the main chemical properties of iodine, the mechanisms of iodine-polymer complexation, and the applications of iodophors.

\section{IODINE: MAIN CHEMICAL PROPERTIES}

Iodine is a chemical element (I) that occurs in the form of iodide salts in nature and is found in marine algae, fish, mollusks, and, to a lower extent, marine water. The chemist Courtois was the first to isolate molecular iodine in 1811 [7], and Gay-Lussac named it as a new chemical element [8].

Iodine exists as slightly lustrous dark-purple crystals at room temperature. When heated at an atmospheric pressure, iodine sublimes to form a purple vapor. When chilled, iodine vapors crystallize without passing through a liquid stage [9].

Iodine is the least reactive halogen and has a relatively low water solubility $(0.33 \mathrm{~g} / \mathrm{L}, 1-2 \mathrm{mM}$ at $25^{\circ} \mathrm{C}$ ). An aqueous solution of iodine is yellowish-brown in color. Iodine readily dissolves in ethanol or diethyl ester to produce brown solutions and in chloroform and benzene to produce purple solutions [10].

The water solubility of iodine increases in the presence of iodide ions, such as potassium iodide, as a result of the formation of water-soluble triiodide ions $\left(\mathrm{I}_{3}^{-}\right)$and slightly increases with the increasing temperature (Fig. 1). Aqueous solutions of iodine are unstable and may contain various ions depending on the conditions. Molecular iodine $\left(\mathrm{I}_{2}\right)$ is thought to possess the highest antimicrobial activity. Iodine stability is strongly affected by $\mathrm{pH}$, and antimicrobial activity decreases with the increasing $\mathrm{pH}$ and the storage time [11]. To better understand the chemical behavior of iodine, Table 1 summarizes the nine main reactions that occur in aqueous solutions containing ten iodine forms: $\mathrm{I}^{-}, \mathrm{I}_{2}, \mathrm{I}_{3}^{-}, \mathrm{I}_{5}^{-}, \mathrm{I}_{6}^{2-}, \mathrm{HOI}, \mathrm{OI}^{-}, \mathrm{HI}_{2} \mathrm{O}^{-}, \mathrm{I}_{2} \mathrm{O}^{-}$, and $\mathrm{H}_{2} \mathrm{OI}^{+}$. Antiseptic properties are only characteristic of $\mathrm{I}_{2}$ (hydrated iodine), $\mathrm{HOI}$ (hypoiodous acid), and $\mathrm{H}_{2} \mathrm{OI}^{+}$ (hydrated iodine cation) among the iodine forms [12].

Rather complex electron absorption spectra are observed for aqueous solutions of molecular iodine and iodine-iodide systems. Absorption bands at $\lambda_{\mathrm{m}}=290,350$, and $460 \mathrm{~nm}$ are characteristic of aqueous solutions of molecular iodine according to literature data. Spectra with absorption bands at $\lambda_{\mathrm{m}}=192-193$ and $226 \mathrm{~nm}$ characterize aqueous solutions of iodides. In the case of a iodine-iodide aqueous solution, the absorption spectrum has maximums at $\lambda_{\mathrm{m}}=192-193,226,290$, and $350 \mathrm{~nm}$. A maximum at $\lambda_{\mathrm{m}}=$ $450-460 \mathrm{~nm}$ is determined by solvated $\mathrm{I}_{2}$ molecules [13]. According to [14], triiodide ion-containing solu- 
Table 1. Main reactions of molecular iodine in water (based on [12])

\begin{tabular}{c|c|l}
\hline Category & Reaction & \multicolumn{1}{c}{ Reaction type } \\
\hline I & $\mathrm{I}_{2}+\mathrm{H}_{2} \mathrm{O} \leftrightarrow \mathrm{HOI}^{+} \mathrm{H}^{+}+\mathrm{I}^{-}$ & Hydrolysis \\
II & $\mathrm{HOI} \leftrightarrow \mathrm{OI}^{-}+\mathrm{H}^{+}$ & Dissociation \\
III & $\mathrm{HOI}+\mathrm{H}^{+} \leftrightarrow \mathrm{H}_{2} \mathrm{OI}^{+}$ & Protonation \\
IV & $\mathrm{I}_{2}+\mathrm{I}^{-} \leftrightarrow \mathrm{I}_{3}^{-}$ & Complexation \\
V & $3 \mathrm{HOI} \leftrightarrow \mathrm{IO}_{3}^{-}+2 \mathrm{I}^{-}+3 \mathrm{H}^{+}$ & Disproportionation \\
VI & $\mathrm{I}_{3}^{-}+\mathrm{I}_{2} \leftrightarrow \mathrm{I}_{5}^{-}$ & Pentaiodide production \\
VII & $2 \mathrm{I}_{3}^{-} \leftrightarrow \mathrm{I}_{6}^{2-}$ & Dimerization \\
VIII & $\mathrm{OI}^{-}+\mathrm{I}^{-}+\mathrm{H}_{2} \mathrm{O} \leftrightarrow \mathrm{HI}_{2} \mathrm{O}^{-}+\mathrm{OH}^{-}$ & Disproportionation \\
IX & $\mathrm{HI}_{2} \mathrm{O}^{-} \leftrightarrow \mathrm{I}_{2} \mathrm{O}^{-}+\mathrm{H}^{+}$ & Dissociation \\
\hline
\end{tabular}

tions show absorption spectra with maximums at $\lambda_{\mathrm{m}}$ of $\sim 290$ and $\sim 353 \mathrm{~nm}$, while molecular iodine has absorption bands at $\lambda_{\mathrm{m}}=270$ and $460 \mathrm{~nm}$.

Electron absorption spectra were recorded for iodine radical anions, iodide ions, and triiodide ions in acetonitrile via light excitation of molecular iodine, tetrabutylammonium iodide, and tetrabutylammonium triiodide [15]. Two absorption bands at $\lambda_{\mathrm{m}}=291$ and $361 \mathrm{~nm}$ were observed for the triiodide ion; two bands at $\lambda_{\mathrm{m}}=208$ and $246 \mathrm{~nm}$, for the iodide ion; while absorption at $\lambda_{\mathrm{m}}>400 \mathrm{~nm}$ was observed for the iodine radical anion (Fig. 2).

The bands at $\lambda_{\mathrm{m}}=290$ and $350 \mathrm{~nm}$ are of applied significance, being observed not only for iodineiodide aqueous solutions, but also for many other solutions of iodide, dihalogens, and iodine-polymers in various solvents. Mokhnach [13] assumed that the absorption maximum at $\lambda_{\mathrm{m}}=290 \mathrm{~nm}$ belongs to the triiodide ion $\mathrm{I}_{3}^{-}$and that the maximum at $\lambda_{\mathrm{m}}=350-360 \mathrm{~nm}$, to the iodine oxyanion $\mathrm{IO}^{-}\left(\mathrm{I}^{+}\right)$.

Spectra of molecular iodine in potassium iodide solutions were recorded using an Analytic Jena UV spectrophotometer (Japan) and a 1-mm quartz cuvette (Fig. 3). As is seen, maximums at $\lambda_{\mathrm{m}}=192$ and $227 \mathrm{~nm}$ are observed in the case of highly diluted solutions, while peaks at 289 and $352 \mathrm{~nm}$ are characteristic of solutions with higher concentrations.

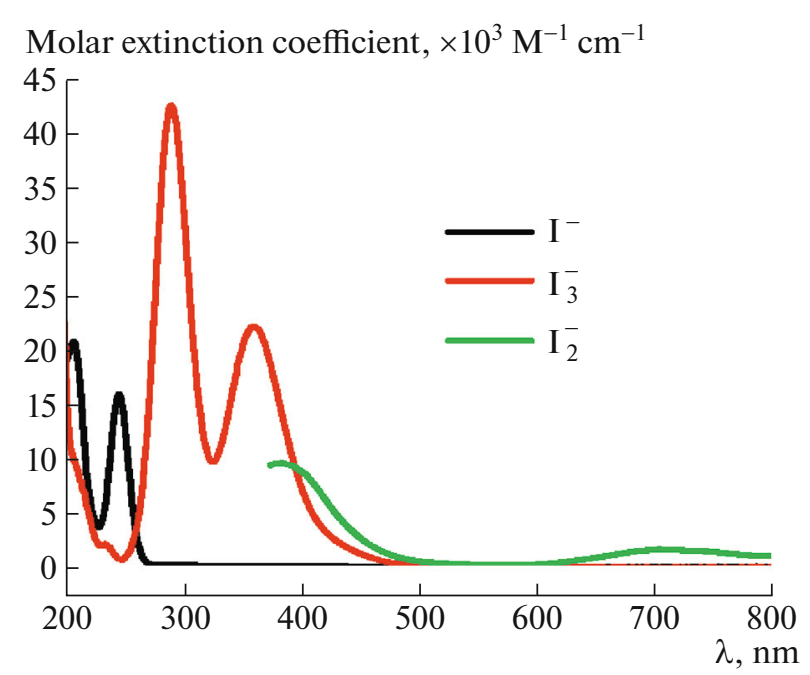

Fig. 2. Absorption spectra of tetrabutylammonium iodide, tetrabutylammonium triiodide, and iodine radical anions in acetonitrile. Reproduced from [15] with permission from the American Chemical Society. 


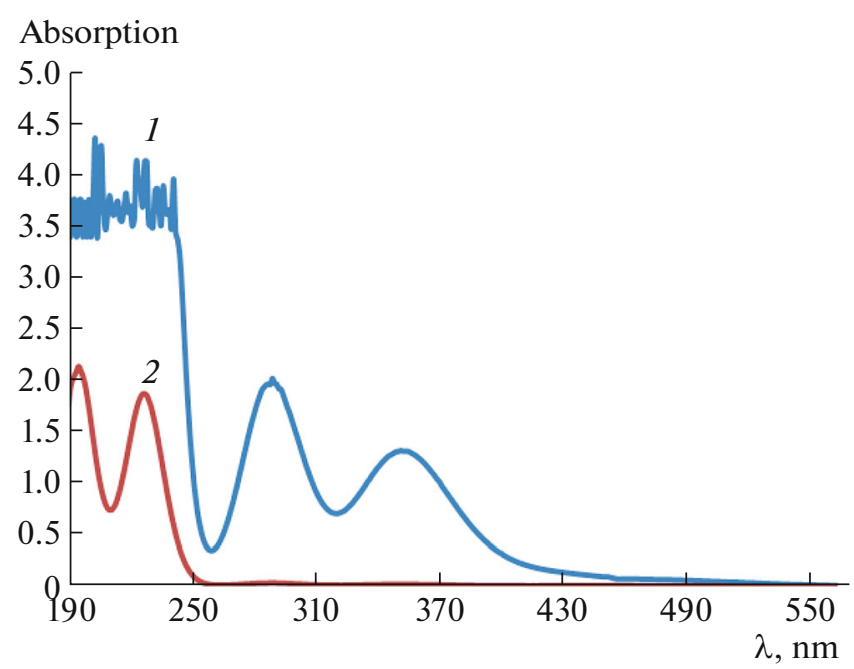

Fig. 3. Absorption spectra of (1) 0.003 and (2) $0.00375 \%$ iodine (aqueous solutions) in the presence of (1) 0.0225 or (2) $0.0005 \%$ potassium iodide.

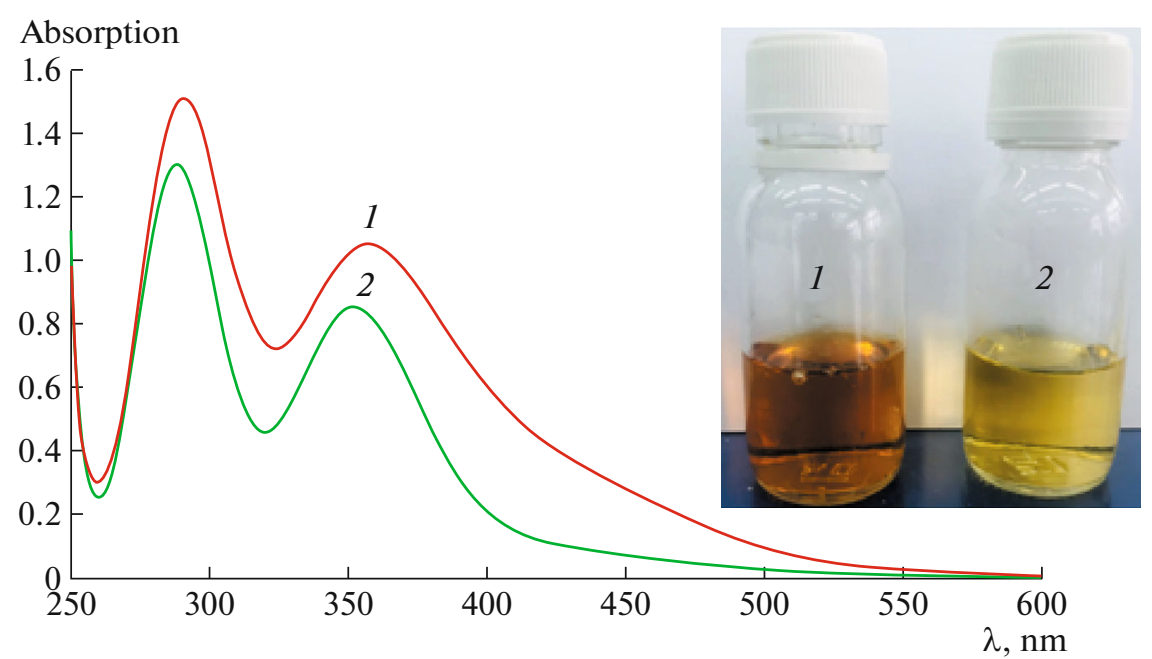

Fig. 4. Absorption spectra of (1) $0.00168 \%$ PVP-iodine and (2) $0.003 \%$ iodine (aqueous solution) with $0.0225 \%$ potassium iodide. The inset shows the (1) PVP-iodine and (2) iodine-iodide solutions.

Absorption bands at $\lambda=290$ and $350 \mathrm{~nm}$ are characteristic not only of aqueous solutions of iodine, but also of iodophor solutions. A bathochromic shift is observed for the well-known iodophor with PVP (Fig. 4); i.e., the absorption maximums shift from 290 and $350 \mathrm{~nm}$ to 293 and $352 \mathrm{~nm}$, respectively, as a result of iodine complexation with the polymer. The complex has an intense color, and the color of its solutions increases in intensity with the increasing iodine concentration.

\section{IODOPHOR PREPARATION: MAIN METHODS AND COMPLEXATION MECHANISM}

Several methods are used to prepare iodophors: polymer dissolution in an aqueous $\mathrm{I}_{2} / \mathrm{KI}$ solution, interactions with iodine vapor, and monomer polymerization in the presence of iodine. An aqueous KI solution is usually added to an iodine-polymer system to improve the $\mathrm{I}_{2}$ solubility and to allow the generation of $\mathrm{I}^{-}, \mathrm{I}_{3}^{-}$, and $\mathrm{I}_{5}^{-}$ions, which are involved in complexation. Complexation is described by the following chemical equations [12]:

$$
\mathrm{I}_{2}+\mathrm{R} \leftrightarrow \mathrm{I}_{2} \cdots \mathrm{R}
$$




$$
\begin{gathered}
\mathrm{I}_{3}^{-}+\mathrm{R} \leftrightarrow \mathrm{I}_{3}^{-} \cdots \mathrm{R}, \quad \text { and } \\
\mathrm{I}^{-}+\mathrm{R} \leftrightarrow \mathrm{I}^{-} \cdots \mathrm{R},
\end{gathered}
$$

where $\mathrm{R}$ is the structural iodophor region that is capable of complexation due to steric and electron factors.

As a Lewis acid, iodine readily reacts with electron donors to produce charge-transfer complexes [16]. The mechanism was confirmed by electron spin microscopy [17]. Electron-rich molecules, which are known as the Lewis bases, include compounds with $\pi$ bonds (in particular, aromatic and heterocyclic compounds) and especially those where electron-donating substituents increase the electron donor potential [18].

Complexes of poly(vinyl alcohol) (PVA) with iodine were studied in detail in many works. As shown by X-ray diffraction, the axis of a polyiodide chain with a periodicity of 3.1 A lies parallel to the orientation direction of PVA [19]. The number of iodine atoms in a polyiodide chain depends on the iodophor preparation method. The widths of X-ray diffraction peaks made it possible to assume that polyiodide chains consist

of at least 15 iodine atoms each and that $\mathrm{I}_{5}^{-}$ions are generated as a result of PVA-iodine complexation [20]. Heyde et al. [21] demonstrated that PVA-iodine complexation is responsible for resonance in Raman spectra and assumed that $\mathrm{I}_{3}^{-}$ions are generated as a result of PVA complexation with molecular iodine.

Helical [22] and aggregate [23-25] models were proposed for the formation of PVA-iodine complexes. In the helical model, iodine ions occur in the inner part of helical PVA chains. Inagaki et al. [26] confirmed the model by demonstrating similar Raman spectra for PVA-iodine and starch-iodine complexes. A combination scattering band at $632.8 \mathrm{~nm}$ is as in the spectrum of starch-iodine complexes, while a band at $155 \mathrm{~cm}^{-1}$ is greatly increased in intensity, the increase being associated with antisymmetric valence vibrations of $\mathrm{I}_{3}^{-}$ions aligned in helical PVA macromolecules. Tebelev et al. [27] assumed that iodine may penetrate into the interior of helical PVA molecules and cavities of their aggregates. The aggregate model assumes that iodine ions occur between PVA chains (sandwich constructs). It was found additionally that syndiotactic PVA forms complexes with iodine more readily than atactic PVA does [23-28]. The syndiotactic form produces a complex with iodine at $30^{\circ} \mathrm{C}$ and lower polymer concentrations in solution, while the atactic polymer does not form complexes in these conditions. Polyiodide chains are presumably incorporated in syndiotactic PVA aggregates to produce complexes (Fig. 5) [29]. Quantum chemical computations revealed hydrogen interactions between the hydrogen atom of a hydroxyl group of PVA and an iodine ion [30].

Small- and wide-angle X-ray scattering experiments were carried out to study fibrillation and complexation during the uniaxial stretching of PVA films in a solution containing $\mathrm{I}^{-} / \mathrm{I}_{2}$ ions. The results showed that nanofibers form during stretching and are periodically packed with a distance of $10 \mathrm{~nm}$ at the last stretching stage. The degree of crystallinity of PVA generally decreases in the presence of iodine as a result of complexation [31].

Povidone-iodine is a complex of PVP with iodine and has a free iodine content of 1-12\% [32]. PVP utilizes the $\mathrm{N}$-carbonyl groups of pyrrole rings to interact with iodine (Fig. 6). Structurally, povidoneiodine consists of protonated PVP units that are linked together via hydrogen bonds and incorporate triiodide anions [33]. The interaction of the polymer with iodine proceeds through two steps. First, iodine, which has pronounced acceptor properties, forms a bond with the lone electron pair of an oxygen atom of a pyrrolidone ring. Second, dissociation of the complex yields iodine atoms, which interact with iodine molecules to produce triiodide ions, which interact in their turn with iodine associated with a pyrrolidone oxygen atom, thus producing intra- and intermolecular ion bridges [34]. Raman spectroscopy showed

that characteristic vibrations of iodine and its polyiodide derivatives $\left(\mathrm{I}_{3}^{-}\right.$and $\left.\mathrm{I}_{5}^{-}\right)$cause strong peaks in the combination scattering spectrum. The peaks occur in the region below $300 \mathrm{~cm}^{-1}$ depending on the method used to prepare the initial povidone-iodine complex. Minor shifts in the position of the carbonyl band to higher values result from the conformational changes that the halogen induces in the polymer structure [35]. Three methods are used to obtain povidone-iodine: exposing the polymer to iodine vapors [36], mixing PVP and iodine solutions [37], and heating dry PVP and iodine samples at $80-90^{\circ} \mathrm{C}$ until the titrated iodine concentration is constant [35].

Starch has been known to interact with iodine since 1814, when Colin and de Claubry [38] studied the effect of iodine on various starch forms in Gay-Lussac's laboratory. The reaction has become one of the main analytical reactions since that time, providing qualitative and quantitative tests for iodine, amylose, and amylopectin compounds [39]. The reaction is used to assess whether apples are ripe and ready to har- 


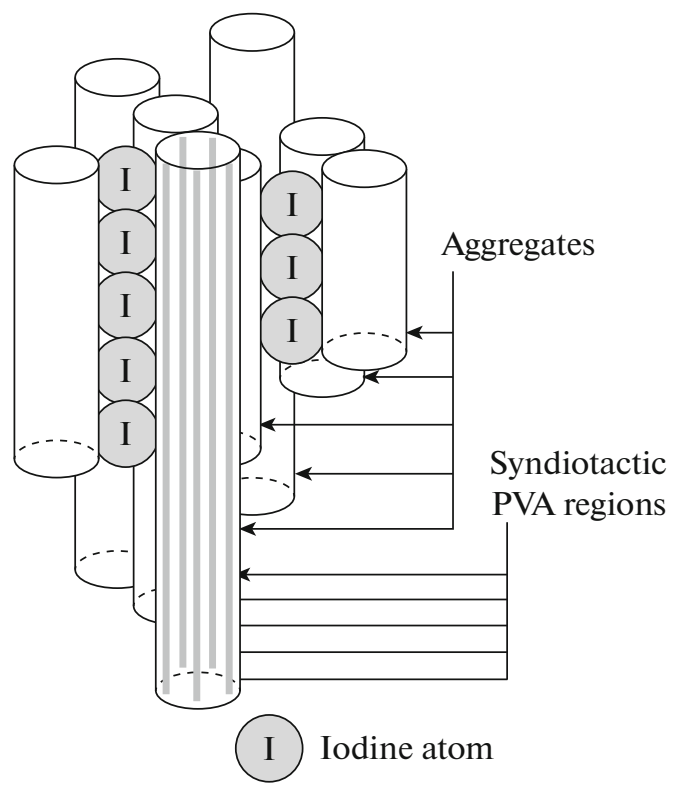

Fig. 5. The aggregate model of PVA-iodine complexes. Reproduced from [29] with permission from John Wiley and Sons.

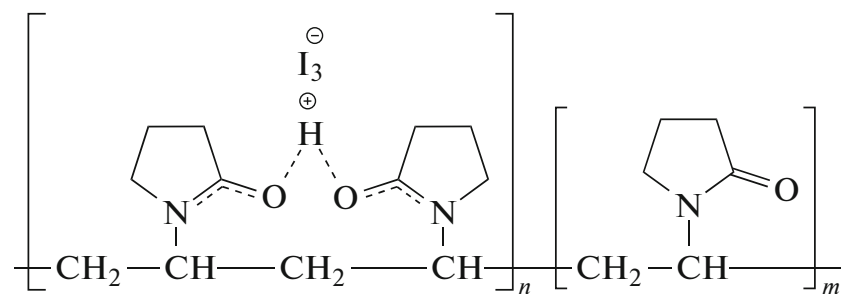

Fig. 6. PVP-iodine complex. Reproduced from [33] with permission from the American Chemical Society.

vest [40], to treat gynecological disorders [13], to correct iodine deficiency [41], to make decisions in treating hyperhidrosis [42], etc. A deep blue-black pellet forms when iodine and starch solutions are combined. Starch consists of linear and helical amylose chains (10-20\%) and branched amylopectin (80$90 \%$ ) (Fig. 7). Starch-iodine is dark blue in color because the amylose-iodine complex has an absorption maximum at $\lambda_{\max }=650 \mathrm{~nm}$ and because iodine affinity is $20 \%$ for amylose and $<1 \%$ for amylopectin. The amylopectin-iodine complex is red-purple and has an absorption maximum at $540 \mathrm{~nm}$ [17]. The starchiodine complex is structurally a left-handed helix with a polyiodide chain, which was studied by titrimetry $[43,44]$. An ordered structure of the starch-iodine complex exists not only in a crystal form, but also in solution on evidence of Raman spectroscopy and UV spectroscopy [45]. Atomic force microscopy showed that starch macromolecules aggregate in the presence of iodine vapor and in iodine-containing solutions to produce fine-dispersed (networks and chains) and complex helical structures depending on the amount of iodine absorbed [46]. Based on spectroscopic studies, oxygens of glycoside and hydroxyl groups of amylose form charge-transfer complexes with iodine [47]. Crosslinked starch derivatives obtained in reactions with epichlorohydrin or 2,3-epoxypropyltrimethylammonium chloride [2] showed high absorption of iodine anions in solutions. Iodine complexes were obtained with the crosslinked cationic starch derivatives $N$-(2-hydroxyl)propyl-3-trimethylammonium starch chloride and $N$-(2-hydroxyl)propyl-3-trimethammonium starch iodide [48]. Ion exchange reactions between the starch derivatives and iodine yielded ionic complexes, which displayed high antibacterial activity towards pathogenic microorganisms from polluted water.

Chitosan is a cationic polysaccharide that results from $N$-deacetylation of chitin, which is a major component of the exoskeleton in arthropods and several other invertebrates and a component of the cell wall in fungi $[49,50]$. Consequently, residual acetylated units are almost always found in chitosan (Fig. 8).

The water solubility of chitosan strongly depends on the $\mathrm{pH}$ of a solution and the extent of deacetylation and the degree of crystallinity of chitosan macromolecules. Figure 9 shows the $\mathrm{pH}$ dependence of the 

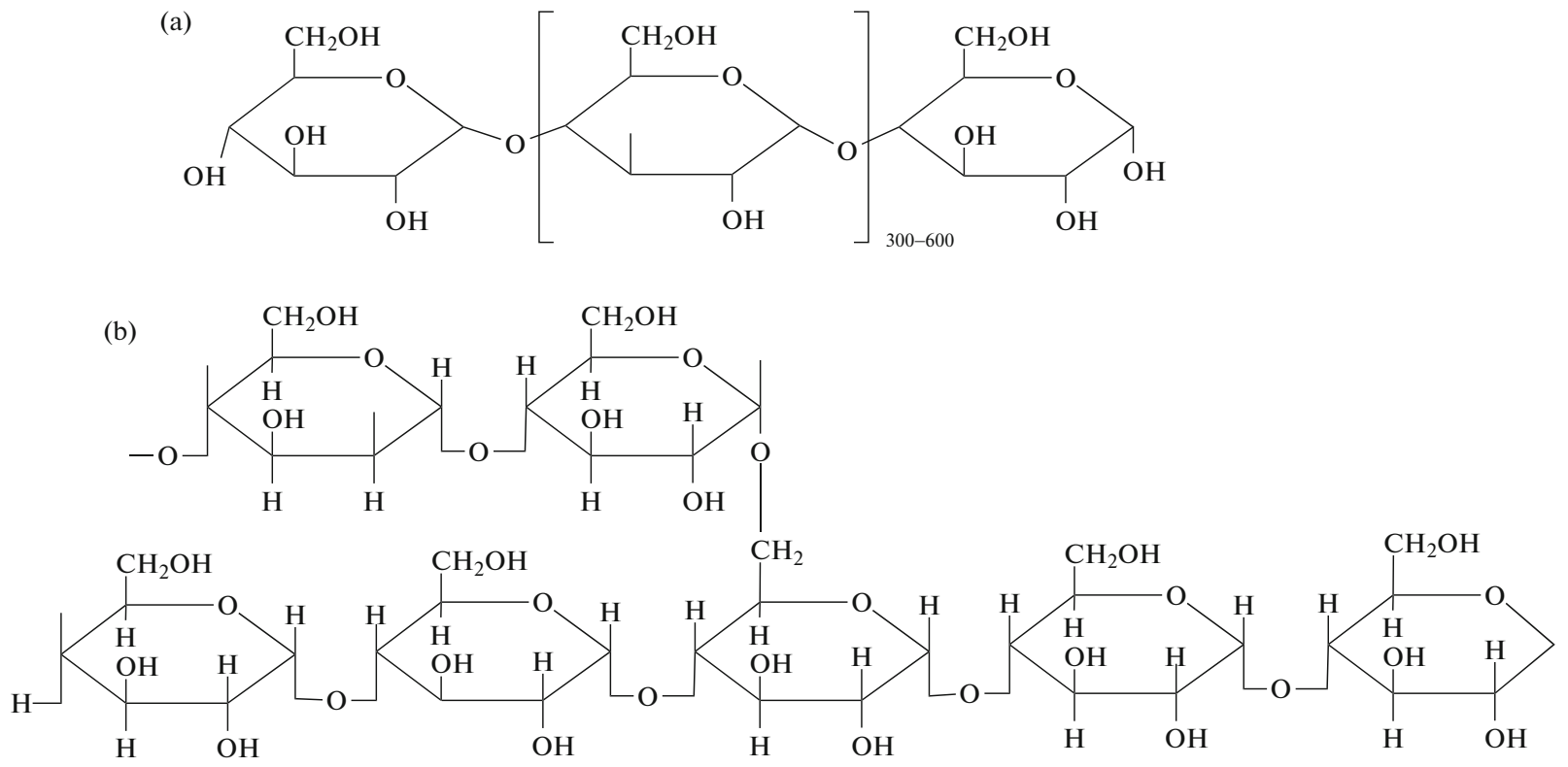

Fig. 7. Structures of (a) amylose and (b) amylopectin

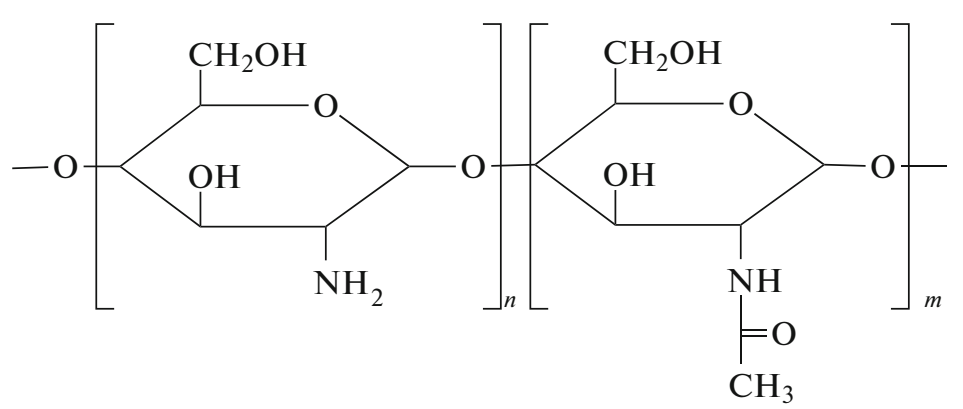

Fig. 8. Chitosan structure.

turbidity of chitosan solutions for chitosan preparations differing in the extent of deacetylation. As is seen, chitosan with a high extent of deacetylation [51] is only soluble in acidic media, while its solutions grow turbid at $\mathrm{pH}>6.5$ [52]. This behavior is observed because chitosan is semicrystalline in nature and because its amino groups can be protonated in acidic media and deprotonated at higher $\mathrm{pH}$ values. Halfacetylated chitosan with an extent of deacetylation of $\sim 50 \%$ is water soluble within a broader $\mathrm{pH}$ range $(\mathrm{pH}<7.2)$, the difference being associated with partial loss of crystallinity because of the less regular distribution of acetylated units. Fully deacetylated chitosan is the least soluble because of its high degree of crystallinity.

A chitosan-iodine complex has an absorption maximum at $500 \mathrm{~nm}$ [53]. Hydroxyl groups and glycoside oxygen atoms of $\mathrm{N}$-acetyl D-glucosamine bind iodine as shown using NMR spectroscopy. Chitosan does not form colored complexes with iodine at room or higher temperatures. However, a purple solution forms upon freezing (Fig. 10). The cause of this interesting behavior is still unknown.

Raman spectroscopy was used to study the interaction of iodine with chitosan [54]. Amino groups were found to mediate the iodine-chitosan interaction. $\mathrm{I}_{3}^{-}$was identified as a main iodine species involved in complexation (the band intensity at $110 \mathrm{~cm}^{-1}$ was far higher than at $169 \mathrm{~cm}^{-1}$ ). The amino groups that are on the outer side of two-fold helical chitosan macromolecules can interact with iodine via physical absorption, being surrounded with $\mathrm{I}_{3}^{-}$ions. Partial oxidation of chitosan by molecular iodine is also possible. Given that acidic conditions are essential for chitosan to dissolve in water, its complexation with molecular iodine is difficult to study because of the presence of extraneous substances. Dry chitosan was 
Turbidity, a. u.

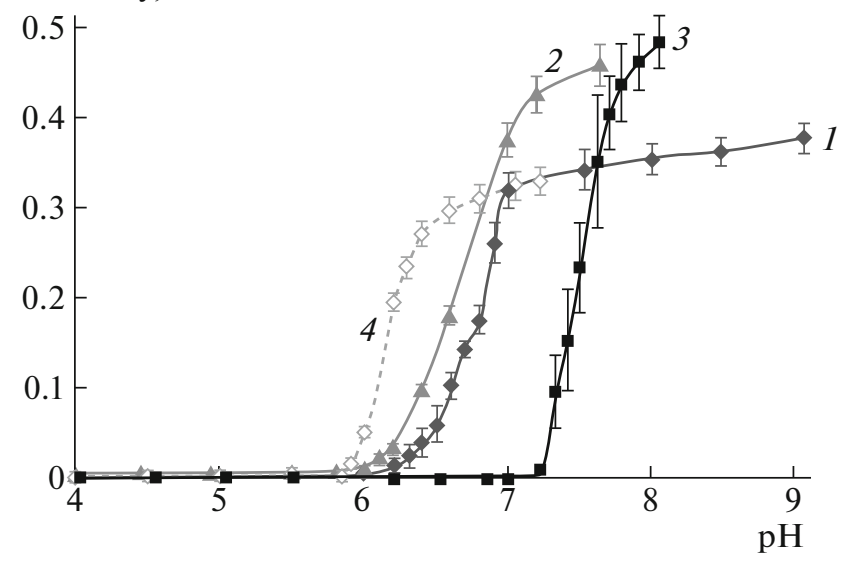

Fig. 9. Effect of $\mathrm{pH}$ on the turbidity of aqueous solutions of (1) chitosan, (2) fully deacetylated chitosan, and (3) halfacetylated chitosan. Curve (4) was obtained for precipitated chitosan after its repeated dissolution. Reproduced from [52] with permission from Wiley and Sons.

(a)

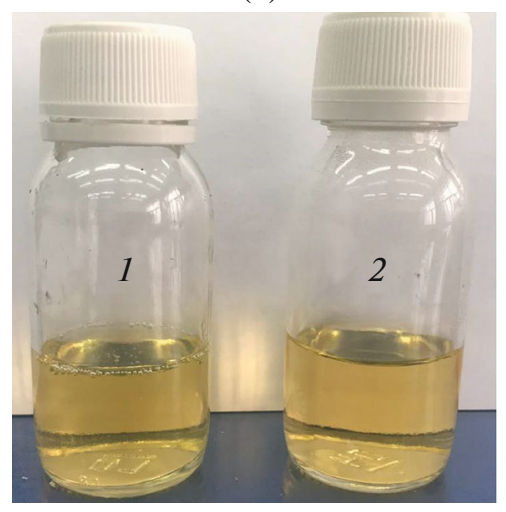

(b)

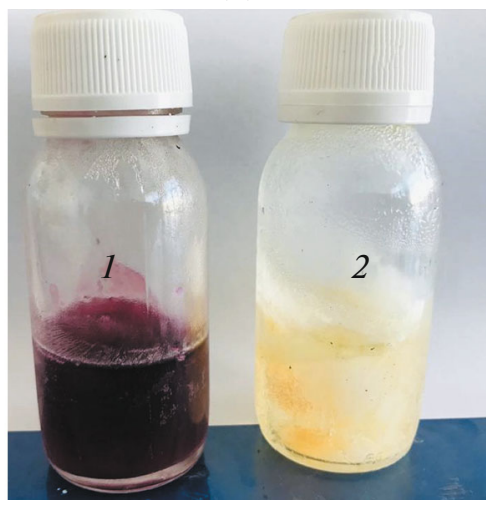

Fig. 10. Color of (1) a chitosan-iodine complex and (2) an iodine solution (a) before and (b) after freezing.

incubated in a hermetically sealed container filled with vapors of crystalline iodine or an iodine-containing solution [55]. Judging from the maximal degree and rate of absorption, absorption of iodine vapor by the polymer over aqueous-alcoholic solutions was substantially higher than over aqueous-salt iodine solutions. The resulting samples were stable over time. Chitosan derivatives are also possible to use to obtain complexes with iodine. For example, Yang Tang et al. [56] prepared a new complex by combining $N-(2-$ hydroxy)propyl-3-methylammonium chloride and chitosan with iodine in ethanol. IR spectroscopy showed that the interaction between iodine and the chitosan derivative is as in charge-transfer complexes; i.e., a negatively charged iodine ion interacts with a positively charged nitrogen atom.

Cellulose and certain cellulose derivatives (Fig. 11) do not form colored complexes with iodine [17, 57]. The structure of cellulose-iodine complexes was studied by X-ray diffraction [58]. An extended rodlike conformation is characteristic of cellulose macromolecules in contrast to amylose. As X-ray crystallography showed, columnar iodine structures are sandwiched between stretched cellulose chains in the complex. Iodine forms charge-transfer complexes with hydroxyl groups of cellulose. Wang et al. [59] studied the interaction of ethylcellulose with iodine. The interaction was found to produce a charge-transfer complex between oxygen of the ester group of ethylcellulose and iodine. Two iodine forms, $\mathrm{I}_{3}^{-}$and $\mathrm{I}_{2}$, were detected in the complex by X-ray photoelectron spectroscopy. Results obtained by differential scanning calorimetry showed that a crystal-liquid crystal transition is induced in the ethylcellulose structure by iodine. The liquid crystalline phase was similarly detected in the complex by circular dichroism spectroscopy. Iodine diffusion into amorphous regions of the polymer can lead to complexation with polymeric 

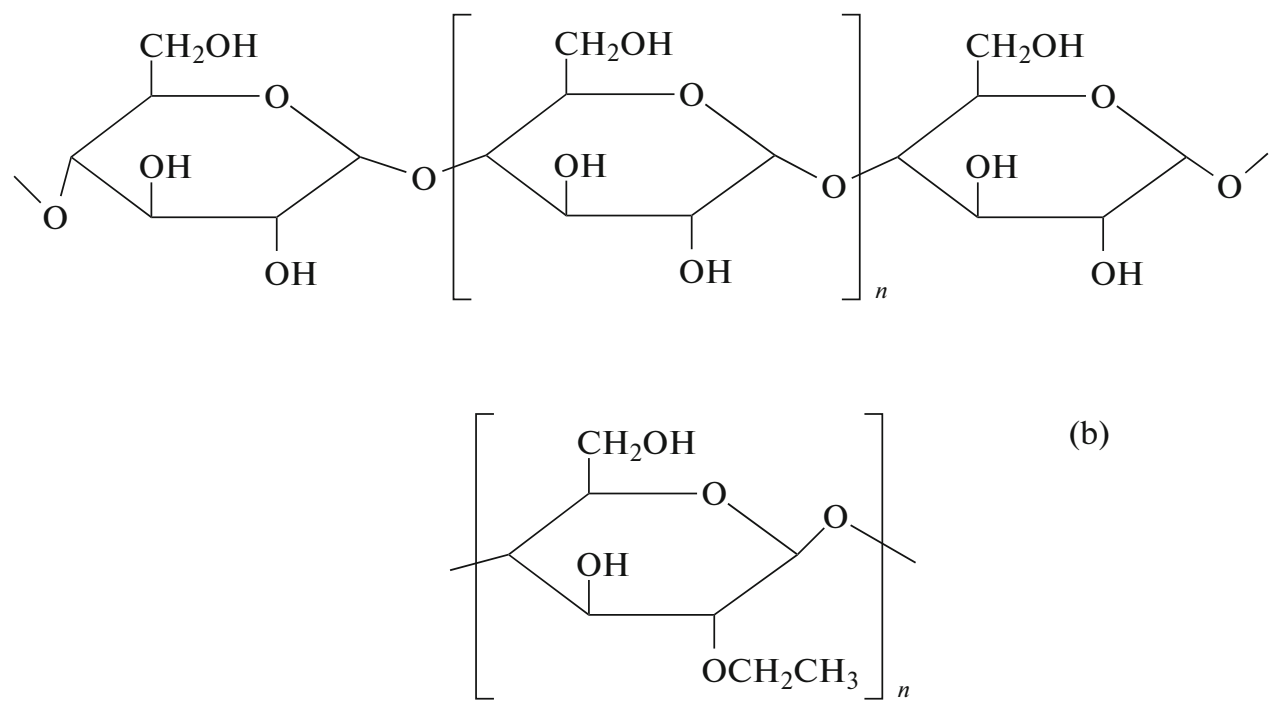

(b)

Fig. 11. Structures of (a) cellulose and (b) ethylcellulose.

chains. A new band or a band shift in the absorption spectrum characterizes the formation of a complex, as in the case of ethylcellulose [60].

Other polymers, such as poly (3-vinyl-10-methylphenothiazine), poly(4-vinylpyridine), and poly(tetramethylene ether) glycol, were tested for iodine absorption [61]. Poly(4-vinylpyridine) and poly(tetramethylene ether) glycol absorbed more than $0.5 \mathrm{~mol}$ of $\mathrm{I}_{2}$ per monomeric unit. An extremely high amount of iodine per monomeric unit was observed with poly(3-vinyl-10-methylphenothiazine), which has an aromatic ring and nitrogen and sulfur atoms as electron donors in its structure. A high absorption capacity is additionally explained by the formation of $\mathrm{I}_{5}^{-}$ions as a result of complexation between $\mathrm{I}^{-}$and $\mathrm{I}_{2}$ and the interaction of $\mathrm{I}_{2}$ with poly(3-vinyl-10-methylphenothiazine).

Linear polyethylene glycol (PEG) is capable of forming complexes with molecular iodine in solution and in a solid state [62]. The PEG-iodine interaction was studied as dependent on the molecular weight of PEG [63]. PEG with a molecular weight of 200 and a degree of polymerization of 5 did not interact with iodine. When the PEG molecular weight was higher, absorption bands were observed in the spectra of complexes at 295 and $365 \mathrm{~nm}$. Thus, a degree of polymerization higher than 6 is a necessary condition for PEG complexation with iodine. The interaction of iodine with PEG results in a charge-transfer complex and occurs between iodine and oxygen atoms of the polymer. The color of the complex depends on the polyoxyethylene chain length [64] and varies from light red to dark brown. Aqueous PEG solutions are capable of extracting iodine from chloroform and carbon tetrachloride solutions [65]. The iodine vapor pressure over a PEG-iodine system is substantially lower than over pure iodine.

\section{APPLICATIONS OF POLYMERIC IODOPHORS}

Iodine-polymer complexes are widely used in pharmacy, veterinary, medicine, disinfectant production, and environmental protection. As mentioned above, iodine is a universal antiseptic, but an irritant effect arises upon its contact with the skin to limit its application. Iodine-containing polymers are free from this drawback and find application as disinfectants and antimicrobial and antibacterial agents. Antibacterial activity of PVP-iodine is observed in a $\mathrm{pH}$ range of 2.5-7.0. Studies in vivo showed that PVPiodine kills $96.7 \%$ of bacteria within $60 \mathrm{~s}$ of its contact with the eye mucosa [66]. PVP-iodine possesses many characteristics necessary for treating wounds and has a broad range of antimicrobial activities [67], affecting viruses [68], fungi [69], and parasites. PVP-iodine does not induce resistance, is more effective with biofilms, is well tolerated, acts on inflamed skin regions, and has an excellent capacity to form films [32]. The iodophor therefore provides an ideal antiseptic for treating the skin and mucous membranes during their preparation to surgery.

Virucidal activity and cytotoxicity in cell cultures were studied for two povidone-iodine drug formulations, an aqueous solution and a liposomal formulation [70]. The aqueous solution and the liposomal formulation of povidone-iodine were similar in virucidal activity against influenza A virus, herpes sim- 
plex virus type 1, adenovirus, and human rhinovirus. A cytotoxic concentration of povidone-iodine was $0.01-0.07 \%$ for the aqueous solution and $0.03-0.27 \%$ for the liposomal formulation. Detection of lactate dehydrogenase release, DNA fragmentation (ELISA), and DNA strand breakage (TUNEL assay) were performed after 24-h exposure of human embryonic lung fibroblasts to povidone-iodine. The results showed that necrosis predominated in cells treated with aqueous $0.08-0.32 \%$ povidone-iodine solutions, while apoptosis predominated in cells treated with equivalent concentrations of the liposomal formulation. The apoptotic pathway of cell death is a regulated process, while necrosis occurs in response to internal and external factors. The liposomal povidone-iodine formulation is therefore more promising as a drug for topical use to prevent and to treat infections of the eye and the upper respiratory tract.

The drug Betadine based on povidone-iodine was used to study the iodophor effect on the human immunodeficiency virus (HIV). The minimal effective Betadine concentration was $0.25 \%$ for complete inactivation of HIV. The result makes it possible to use povidone-iodine as a topical antiseptic against HIV in clinics and laboratories [71]. Six preparations based on povidone-iodine with concentrations of $0.23-2 \%$ were tested for effect on avian influenza A virus [72]. To study the effect, $0.25 \mathrm{~mL}$ of a povidone-iodine preparation were combined with $0.25 \mathrm{~mL}$ of a test virus preparation and incubated at $25^{\circ} \mathrm{C}$ for $10 \mathrm{~s}$. The reaction was terminated by adding a phosphate buffer supplemented with $0.5 \%$ sodium thiosulfate. As the results showed, virus strains were reduced below the detection limit by incubation with all PVP-iodine preparations for only $10 \mathrm{~s}$, demonstrating the efficacy of povidone-iodine as a preventive and therapeutic treatment against avian influenza A viruses. A Japanese team studied inactivation of several virus strains, including adenoviruses, rotaviruses, mumps, poliomyelitis (types 1 and 3), Coxsackie, herpes simplex, rubella, measles, influenza, and human immunodeficiency viruses, by povidone-iodine and other commercially available antiseptics, using standardized in vitro techniques [68]. The following antiseptics were tested: a povidone-iodine solution, a povidone-iodine gargle, a povidone-iodine cream, chlorhexidine gluconate, alkyldiaminoethylglycine hydrochloride, benzalkonium chloride (BAC), and benzethonium chloride (BEC). The povidone-iodine products completely inactivated herpes, rubella, mumps, influenza, nonenveloped rota-, and polioviruses and HIV, while enveloped measles, adeno-, nonenveloped rhino-, and polioviruses were partly sensitive to the maximal product dose. Rubella, measles, and mumps viruses and HIV were sensitive to all antiseptics; rotavirus was inactivated by BAC and BEC; and adeno-, polio-, and rhinoviruses did not respond to the commercial antiseptics. Thus, povidone-iodine has a broader spectrum of antivirus activity, covering both enveloped and nonenveloped viruses, as compared with other commercial antiseptics.

Severe acute respiratory syndrome caused by a coronavirus (SARS-CoV) was first detected in November 2002 in Guangdong, China. The virus caused 774 human deaths in the period from November 2002 to July 2003 [74]. Antivirus activity against coronavirus was studied for povidone-iodine [75]. SARS-CoV treatment with povidone-iodine products for 2 min decreased the infectious titer from $1.17 \times 10^{6} \mathrm{TCID}_{50} / \mathrm{mL}$ (a $50 \%$ tissue culture infectious dose) to a level below the detectable limit. The efficacy of povidone-iodine was equivalent to that of $70 \%$ ethanol. Use of povidone-iodine sprays and gargles is of importance as a preventive measure. A new coronavirus, SARS-CoV-2, emerged in the Wuhan province, China, in the last decade of 2019. March 11, 2020, SARS-CoV-2 was declared a pandemic by the World Health Organization. Sprays containing $0.5 \%$ povidone-iodide are proposed to use at $0.28-0.30 \mathrm{~mL}$ in each nostril by patients and healthcare professionals [75]. The total iodine dose is approximately $0.33 \mathrm{mg}$ in this case and is not expected to cause any side effect. Mouth washing with $9 \mathrm{~mL}$ of $0.5 \%$ povidone-iodine for $30 \mathrm{~s}$ was proposed in [73]. The total iodine dose is approximately $0.05 \mathrm{mg}$ in this case. Single povidone-iodine administration was shown to reduce the mouth microflora for $3 \mathrm{~h}$.

In veterinary, povidone-iodine is broadly used to treat various swellings, strained ligaments, blunt injuries, and ulcers hard to cure in domestic animals and to disinfect the funicular cord in newborn foals and calves [32].

There are more than 400 brand names of pharmaceutical preparations (generics) based on iodinepolymer complexes worldwide [76]. Iodine complexes with PVP and PVA are the most common active substances. As summarized in Table 2, the main uses of these drugs include mostly primary treatment of the skin, open wounds, and infected sites and disinfection of various devices and body regions before surgery. Povidone-iodine solutions are known to be effective as shampoo additives against head skin microorganisms [32].

INADINE non-adherent dressing consists of a low-adherent fabric impregnated with PEG and containing $10 \%$ povidone-iodine with $1 \%$ free iodine. INADINE dressing proved to be effective as nonadherent antiseptic dressing for primary treatment of wounded skin regions. A comprehensive review was performed using the results from clinical studies of dressings with iodine compounds [77]. Iodine-containing dressings were found to be superior to dressings with sulfadiazine and inferior to dressings with 
Table 2. Commercially available iodine-polymer drugs (based on the data from [80-84])

\begin{tabular}{|c|c|c|c|c|}
\hline Drug & $\begin{array}{l}\text { Active substance, } \\
\text { strength }\end{array}$ & Manufacturer & Formulation & Drug effect \\
\hline Betadine & $\begin{array}{l}\text { Povidone-iodine } \\
(0.25-10 \%)\end{array}$ & $\begin{array}{l}\text { Avrio Health (United } \\
\text { States), MundiPharma } \\
\text { (United Kingdom) }\end{array}$ & \begin{tabular}{|l|} 
Solution for topical \\
external use, vaginal \\
pessaries, ointment for \\
external use, vaginal gel
\end{tabular} & $\begin{array}{l}\text { Antibacterial and anti- } \\
\text { septic drugs to use in } \\
\text { both humans } \\
\text { and animals }\end{array}$ \\
\hline Recuro Vaginal & $\begin{array}{l}\text { Povidone-iodine } \\
(0.30 \%)\end{array}$ & $\begin{array}{l}\text { Iona Pharmacy LLC } \\
\text { (United States) }\end{array}$ & Douche & \\
\hline Akvazan & Povidone-iodine (10\%) & $\begin{array}{l}\text { OOO Iodnye Tekh- } \\
\text { nologii i Marketing } \\
\text { (Russia) }\end{array}$ & $\begin{array}{l}\text { Solution for topical } \\
\text { external use }\end{array}$ & \\
\hline Iodovidon & $\begin{array}{l}\text { Povidone-iodine } \\
(0.50 \%)\end{array}$ & Altaivitaminy (Russia) & $\begin{array}{l}\text { Spray for external topi- } \\
\text { cal use }\end{array}$ & \\
\hline Iovidoks & $\begin{array}{l}\text { Povidone-iodine } \\
(200 \mathrm{mg})\end{array}$ & $\begin{array}{l}\text { Tula Pharmaceutical } \\
\text { Factory (Russia) }\end{array}$ & Vaginal pessaries & \\
\hline Iodosept & $\begin{array}{l}\text { Povidone-iodine } \\
(200 \mathrm{mg})\end{array}$ & YuzhFarm (Russia) & Vaginal pessaries & $\begin{array}{l}\text { Antibacterial and anti- } \\
\text { septic drugs to use in }\end{array}$ \\
\hline $\begin{array}{l}\text { Iodinol (Blue } \\
\text { iodine) }\end{array}$ & PVA-iodine (1\%) & $\begin{array}{l}\text { Ivanovo Pharmaceuti- } \\
\text { cal Factory (Russia), } \\
\text { Troitsk Iodine Factory } \\
\text { (Russia) }\end{array}$ & $\begin{array}{l}\text { Solution for external } \\
\text { use }\end{array}$ & $\begin{array}{l}\text { both humans and ani- } \\
\text { mals }\end{array}$ \\
\hline Jox & $\begin{array}{l}\text { Allantoin }+ \text { povidone- } \\
\text { iodine }(8.5 \%)\end{array}$ & $\begin{array}{l}\text { Ivax Pharmaceuticals } \\
\text { s.r.o. (Czech Republic) }\end{array}$ & Spray for topical use & $\begin{array}{l}\text { Anti-inflammatory } \\
\text { drug }\end{array}$ \\
\hline Inadine & Povidone-iodine (10\%) & $\begin{array}{l}\text { Kinetic Concepts, Inc. } \\
\text { (United States) }\end{array}$ & Non-adhesive dressing & Antibacterial dressing \\
\hline $\begin{array}{l}\text { Iodosorb, } \\
\text { Iodoflex }\end{array}$ & $\begin{array}{l}\text { Cadexomer }+ \text { iodine } \\
(0.9 \%)\end{array}$ & $\begin{array}{l}\text { Smith \& Nephew } \\
\text { (United Kingdom) }\end{array}$ & Gel and dressing & $\begin{array}{l}\text { Antibacterial } \\
\text { treatment aids }\end{array}$ \\
\hline Iodozyme & $\begin{array}{l}\text { Gel }+ \text { iodine, free } \\
\text { iodine content } 0.20 \% \\
\text { by weight [84] }\end{array}$ & $\begin{array}{l}\text { Archimed LLP (United } \\
\text { Kingdom) }\end{array}$ & $\begin{array}{l}\text { Wound-healing } \\
\text { dressing }\end{array}$ & $\begin{array}{l}\text { Antibacterial dressing } \\
\text { to treat infected } \\
\text { wounds and ulcers }\end{array}$ \\
\hline
\end{tabular}

rifamycin. Distortion of the thyroid function and worsening of wound healing were not observed with iodinecontaining dressings. In addition, 5\% iodine-PVP ointment was found to be superior to silver sulfadiazine in wound healing [78]. The drug was shown to be effective and well tolerated in pediatric patients [79].

Microbial infection of a burn wound may have a substantial effect because microorganisms can facilitate a progression of partial-thickness burns to full-thickness burns with severe sequels. PVP-iodine ointments were used to treat patients with burns of various sizes in combination with antibiotics and systemic administration of vitamins $\mathrm{E}$ and $\mathrm{C}$ to alleviate oxidative stress in burn wounds [85]. The ointments containing PVP-iodine showed an efficacy of $15.3 \%$ and a wound healing time of 4 days, thus helping to reduce the hospital stay costs. Moreover, no adverse effect was observed. The effects that PVP-iodine exerts on neutrophils and oxygen radicals are of special importance in patients with concomitant skin injuries (for example, open bleeding). Landsman et al. [86] designed shape memory polymeric hemostatic materials based on PEG acrylate-PVP-iodine hydrogel to control wound hemorrhages. Hydrogels increased fluid uptake by a factor of 19 as compared with hydrogels without povidone-iodine and showed high antibacterial activity. Hemostatic macroporous polymer foams were synthesized via high dispersed (internal) phase emulsion templating on the basis of PEG and sodium acrylate [87]. The polymer foams were soaked with an iodine solution to impart antimicrobial activity. Extended release of iodine for $48 \mathrm{~h}$ was achieved with higher iodine concentrations in solutions, while fast release was observed at lower concentrations. The complexes demonstrated activity against Escherichia coli, Klebsiella pneumoniae, Pseudomonas aeruginosa, and Staphylococcus aureus bacteria.

Lecithin is a surface-active substance that binds iodine well. Lecithin is used to obtain polymeric films (dressings) to ensure a uniform distribution of iodine. Hydroxylated lecithin was used to improve the 


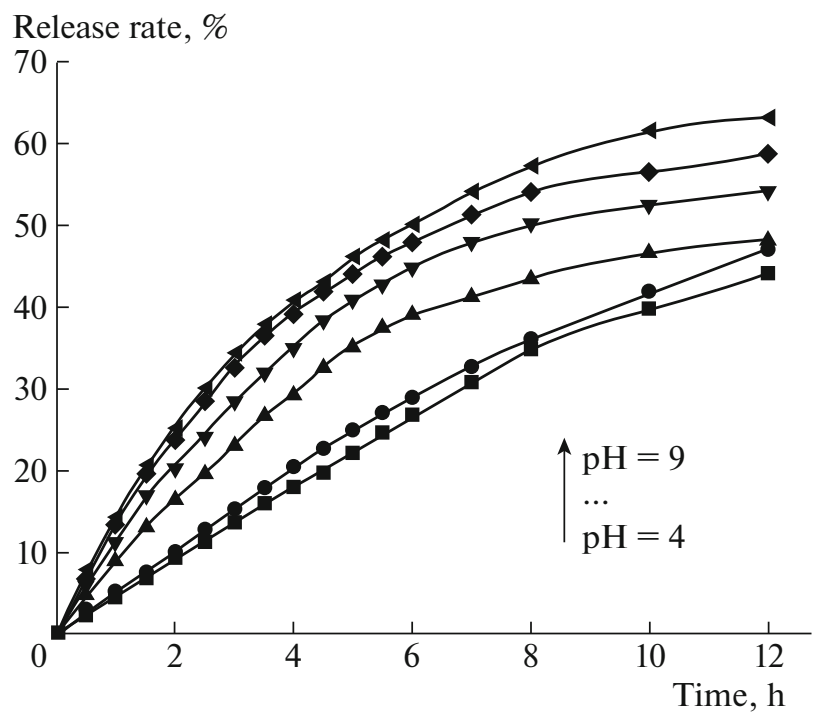

Fig. 12. Effect of $\mathrm{pH}$ on iodine release. Reproduced from [82] with permission from Elsevier.

iodine complexation capacity of a composite film based on carboxymethyl cellulose and sodium alginate [88]. The resulting composite films showed a high iodine content, good swelling properties, $\mathrm{pH}$-controlled release of iodine (Fig. 12), and excellent antibacterial properties. Iodine release from the composite films obeyed the diffusion laws and Higuchi model. The iodine release rate increased with the increasing $\mathrm{pH}$. An increase in $\mathrm{pH}$ leads to dissociation of $\mathrm{COOH}$ groups in lecithin, breakage of hydrogen bonds, and electrostatic repulsion of negatively charged carboxyl groups, thus allowing faster release of iodine from a composite film.

An iodine complex with sodium acrylate and $N$-vinylpyrrolidone copolymers combined with carboxymethyl chitosan was used to prevent postsurgical infection after treating vaginal disorders [90]. Results from clinical studies showed that the composition in question is more effective than the standard treatment method.

A 10\% PVP-iodine was tested at various dilutions as an agent for field water disinfection against $E$. coli [91]. Optimal conditions for suppressing $E$. coli colony formation were identified as a $1: 1000$ dilution of $10 \% \mathrm{PVP}$-iodine, a contact time of $15 \mathrm{~min}$, and a temperature of $10-30^{\circ} \mathrm{C}$. The free iodine content is approximately $10 \mathrm{mg}$ per $1 \mathrm{~L}$ of water in the $1: 1000$ dilution of $10 \% \mathrm{PVP}-$ iodine. This free iodine content is the safest for urgent field water disinfection.

Polymeric composite membranes based on a chitosan-PEG-multi-walled carbon nanotube system and impregnated with iodine were used to solve the problem of bacterial adhesion to membrane filter surfaces [92]. To obtain the membranes, an acidified chitosan solution was combined with a solution containing, membranes were molded, and iodine was incorporated by phase reversal. Iodine incorporation increased the hydrophilicity and porosity of a membrane. The free iodine content was $0-0.31 \mathrm{wt} \%$ in the composite membranes (CM-0, CM-0.10, CM-0.17, and CM-0.31). The composite membranes showed a high efficiency against $E$. coli and $S$. aureus at an iodine concentration of $0.31 \mathrm{wt} \%$, the bactericidal efficiency coefficient being 99.2 and 100\%, respectively (Fig. 13).

Iodine and iodine compounds are broadly used as contrasting agents in computed tomography and magnetic resonance imaging [93]. Most of the available contrasting agents are ionic and nonionic iodine complexes. A pressing problem is to design iodinated contrasting agents that persist in the blood for a longer period of time. Polymer-iodine complexes are potentially capable of meeting this requirement because many biomedical polymers are hemocompatible. For example, multilayered particles were constructed of a $\mathrm{CaCO}_{3}$ core and polymer-iodine layers absorbed on the core [94]. Nontoxic biodegradable chitosan was used for complexation with iodine. The maximal iodine load was $450 \mathrm{mg}$ per $1 \mathrm{~g}$ of calcium carbonate. Unique nanoparticles of iodine covalently bound to PEG showed a half-life of $40 \mathrm{~h}$ in the blood [95]. This feature makes it possible to use the nanoparticles to visualize microvessels and tumor masses. Toxicity of iodine-containing nanoparticles was studied in mice, which were injected intravenously at $4 \mathrm{~g}$ iodine per kg body weight. Saline was injected to control mice. The mice injected with $4 \mathrm{~g}$ of iodine per $1 \mathrm{~kg}$ body weight showed a normal weight gain as compared with the control mice and lived 


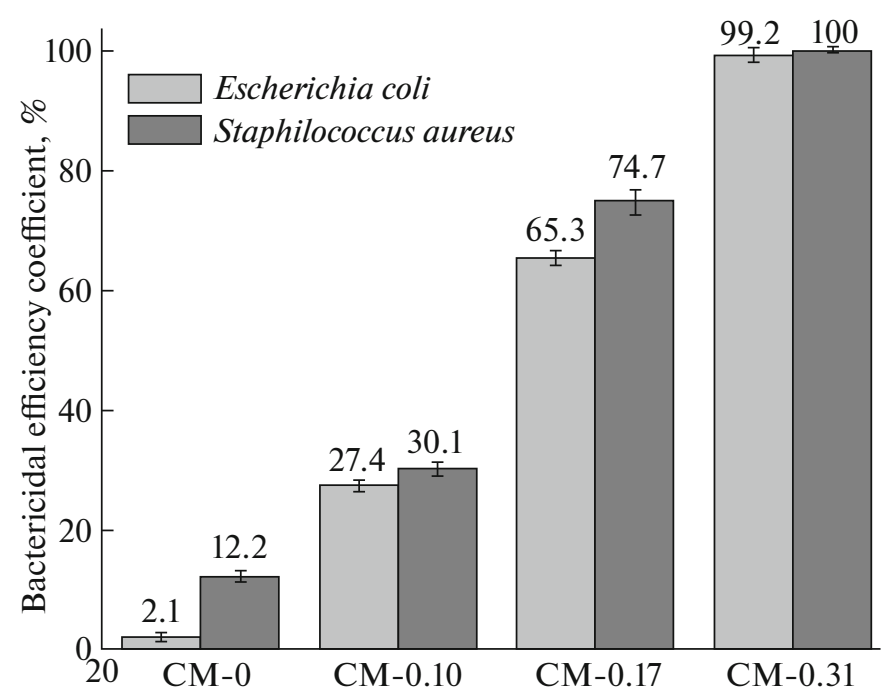

Fig. 13. Bactericidal effect of composite membranes based on chitosan/PEG/multi-walled carbon nanotubes and impregnated with iodine (CM-0, CM-0.10, CM-0.17, and CM-0.31) against E. coli and S. aureus. Reproduced from [85] with permission from Elsevier.

over 1 year without any undesirable clinical effect. Complete blood count and metabolic studies were performed after 40 days of administration of iodine-containing nanoparticles and showed normal results and lack of nanoparticle toxicity.

To treat iodine deficiency [96], it was proposed that tomatoes are immersed in a chitosan-iodine solution. An edible chitosan-iodine film thus forms and contains an iodine dose corresponding to reference daily intake (approximately $0.4 \mu \mathrm{g}$ of iodine per weight of one tomato). The film increases the shelf life of tomatoes, which remain good longer.

Another promising area is designing new formulations for targeted iodine delivery to body sites that are difficult to access and increasing the period of iodine action. For example, povidone-iodine was found to be suitable for treating conjunctival infections [97]. Another study demonstrated the efficacy of povidone-iodine against pathogenic vaginal bacteria [98].

In certain cases, PVP-iodine is of limited utility because its residence on a mucous membrane is not long enough to treat microbial infections. PVP is a nonionic polymer and lacks a high adhesion capacity to mucous membranes [99]. To improve the mucoadhesive properties of PVP and PVP-iodine, thiolated particles were synthesized via copolymerization of $N$-vinylpyrrolidone with 2-(2-acryloylethyldisulfanyl)nicotinic acid [89]. The resulting thiolated particles were well capable of producing gels with pig gastric mucin in higher-viscosity conditions. Thiolated PVP-iodine complexes were found to have a greater potential for residing on mucous membranes and can be recommended for use as disinfecting agents to prevent microbial infections. To study the rate of iodine release from polymer-iodine complexes (PVPiodine and three complexes with thiolated PVP variants (PVP-1, PVP-2, and PVP-3)), experiments were carried out with pig intestinal mucosa samples in a phosphate buffer at $\mathrm{pH} 6.8$ for $3 \mathrm{~h}$. Longer iodine release was observed with thiolated PVP-iodine complexes (50-70\%) compared with PVP-iodine (more than 90\%) (Fig. 14).

To improve the mucoadhesive properties and iodine suitability for disinfecting mucous membranes in the body, oxidized $\alpha$-cyclodextrin was modified with cysteine-2-mercaptonicotinic acid [100]. Thiolated $\alpha$-cyclodextrin possesses good mucoadhesive properties, forming disulfide bonds with cysteine-rich subdomains of the glycoprotein mucin $[99,101]$, and has a unique capability of forming inclusion complexes with hydrophobic drugs [102]. In addition, $\alpha$-cyclodextrin is better soluble in water and forms more stable complexes with iodine as compared with other cyclodextrins [103]. As a result of the above modification, the iodine release in vitro was $15 \%$ per hour and mucoadhesive properties increased by a factor of 38 .

Hydrogel of a charge-transfer complex type was obtained on the basis of a chitosan solution acidified using acetic acid and an iodine solution in the presence of glycerol [104]. The resulting chitosan-iodine complexes were highly viscous and formed gel, which disappeared upon shaking. The complex color varied from dark brown to orange or yellow, depending on the initial substance concentrations. When the complexes were used to treat wounds, healing was quite rapid and the skin was not stained. Gel of chi- 


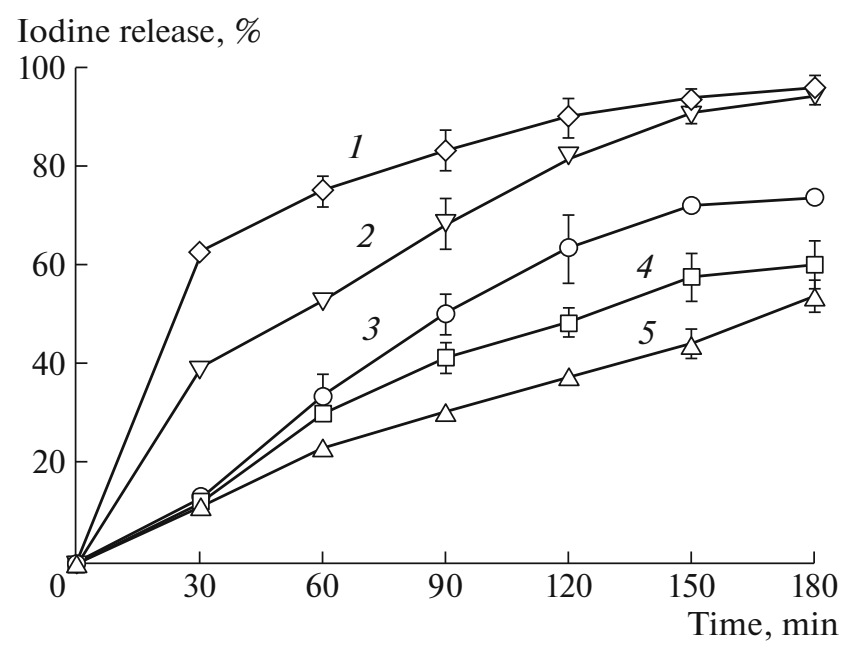

Fig. 14. Iodine release from (2) PVP-iodine and the thiolated PVP-iodine complexes (3) PVP-1, (4) PVP-2, and (5) PVP-3. Control curve 1 was obtained with free iodine. Reproduced from [89] with permission from the American Chemical Society.

tosan, povidone-iodine, and alginate nanoparticles was obtained by ionic gelation [105]. Chitosan nanoparticles with vancomycin were obtained by ionic gelation in the presence of penta-sodium tripolyphosphate as described in [106]. Then crosslinking was induced in an alginate solution containing povidone-iodine and chitosan nanoparticles with vancomycin to obtain gel. Its antibacterial properties, hemocompatibility, and prolonged release of povidone-iodine and vancomycin over 10-15 days open the possibility of using the gel to treat complications of prosthesis placement. To study hemocompatibility of alginate gels with povidone-iodine and chitosan nanoparticles, the gels were incubated with red blood cells in saline. Percent hemolysis was estimated at 5\% with all compositions, pointing to good hemocompatibility. A minor extent of hemolysis was attributed to the positive $\zeta$ potential of chitosan nanoparticles. Red blood cells were additionally examined for changes in morphology in contact with gels of various compositions, and no change was observed with the exception of membrane rupture in a few cells. Cell viability remained $80 \%$ after $24-, 48-$, and $72-\mathrm{h}$ incubation with extracts of alginate gels containing povidone-iodine and chitosan nanoparticles. Cell morphology remained unchanged. The observations indicate that gels of various compositions are safe to test in clinical and preclinical studies.

New composite dressing was obtained by combining sodium alginate and povidone-iodine solutions and showed good therapeutic results in healing wounds [107]. Human foreskin fibroblasts were treated with an extract of sodium alginate/povidine-iodine for $24 \mathrm{~h}$ and proved to exert no effect on cell viability; i.e., 93.2\% of cells remained viable (Fig. 15). All in vitro procedures were performed according to ISO 10993 standards. Complete wound healing was achieved in 12 days. Complete biocompatibility was demonstrated for dressings based on sodium alginate and povidone-iodine.

Sai et al. [108] prepared chitosan grafted PVP gel with iodine by combining a PVP-chitosan-iodine solution with gelatin. Chitosan grafted PVP copolymer was prepared by chitosan grafting to PVP at sites of $\mathrm{N} 2$ protection with diethyl 2,2'-azobis(2-methylpropionate) as an initiator. An iodine complex with the polymer was obtained by adding a small amount of iodine solution in ethanol. The properties of the complex were studied by UV spectroscopy, IR spectroscopy, and thermogravimetric analysis. The results of iodine release experiments corresponded to the release kinetic model-Fick diffusion laws. That is, a burst effect was observed first, and the drug was initially released at a higher rate. Then the process remained stable for a certain period of time, demonstrating iodine release at a lower rate. Inhibition zone diameters observed with chitosan-PVP-iodine-gelatin gel against $S$. aureus and E. coli were greater than $16 \mathrm{~mm}$, suggesting high antibacterial activity. The above advantages of the system make it highly promising as a source of new biomedical sterilization materials. In another study, a membrane was prepared from a mixture of gelatin, PVP, and a hydroxypropyl chitosan biguanide chloride copolymer [109]. The membrane showed good iodine absorption and sustained iodine release at lower temperatures.

Iodophors are broadly used not only in medicine, but also in other fields. PVA-iodine films are widely used as plates for liquid crystal displays owing to their excellent polarizing properties [110, 111]. Plates are industrially manufactured by immersing stretched PVA films in an aqueous $\mathrm{KI}-\mathrm{I}_{2}$ solution. 


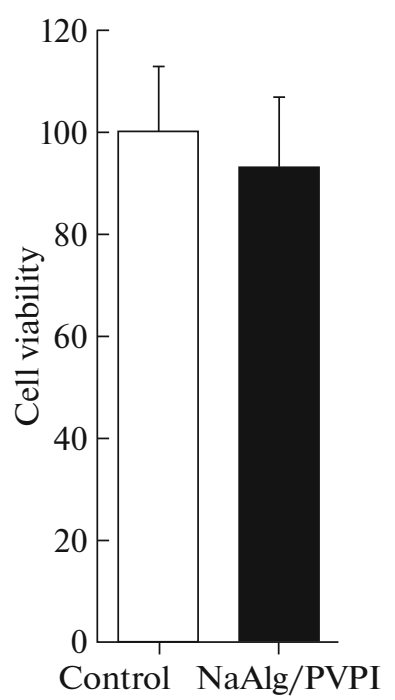

Fig. 15. Viability of human foreskin fibroblasts treated with an extract of sodium alginate/povidone-iodine for $24 \mathrm{~h}$ as compared with a control sample (100\%). Reproduced from [107] with permission from Elsevier.

Pollution with industrial wastes is a major problem of modern industries, being dangerous and presenting a threat to the environment. Iodine is one of the products of nuclear power industry. A dose of $2-3 \mathrm{~g}$ of molecular iodine is lethal for humans, and iodine solutions exert an irritant effect on the skin and mucous membranes [1]. Therefore, designing an efficient strategy to trap and remove iodine from industrial wastewaters is of importance on a nationwide scale. A polymer was obtained for the purpose with Nvinylpyrrolidone and vinylacetate by one-step radical copolymerization with a regulated composition of the initial monomer mixture [112]. The $\mathrm{N}$-vinylpyrrolidone-vinylacetate $(N$-VP-VA) copolymer was used as an absorbent to remove iodine from various solvents, including water, ethanol, cyclohexane, and petroleum ether. Iodine was readily released from the $(N-\mathrm{VP}-\mathrm{VA})$ copolymer in the presence of starch and bacteria. Figure 16 shows the concentration dependence of antibacterial activity of the ( $N$-VP-VA)iodine complex against $E$. coli and $S$. aureus. The pure ( $N$-VP-VA) copolymer was incapable of killing bacteria in a concentration range of $0.01-0.5 \mathrm{mg} / \mathrm{L}$, while the degree of sterilization achieved with the complex of the ( $N$-VP-VA) copolymer with iodine reached $24 \%$ in the case of $E$. coli and $32 \%$ in the case of $S$. aureus at a sample concentration of $0.01 \mathrm{mg} / \mathrm{L}$. When the concentration was higher than $0.05 \mathrm{mg} / \mathrm{L}$, a $100 \%$ degree of sterilization was observed with both $E$. coli and $S$. aureus. The results open new prospects for safe elimination of iodine and antibacterial applications. The copolymer-iodine complex may find broad use in environmental restoration and public health. Microspheres of crosslinked chitosan [113] and chitosan with silver chloride [114] similarly showed high efficiencies in removing radioactive iodine from wastewaters. High absorption capacity of microspheres was preserved after several regeneration cycles.
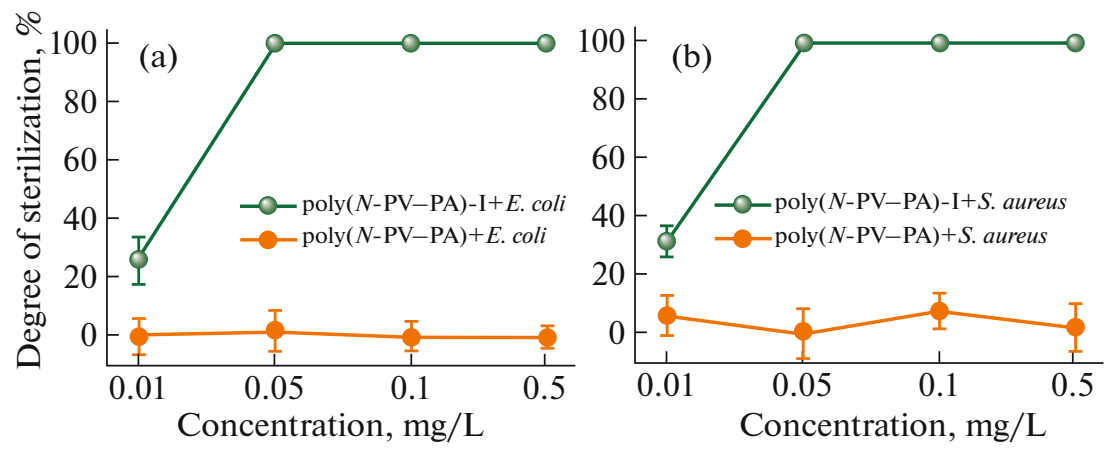

Fig. 16. Antibacterial activity of poly $(N-\mathrm{PV}-\mathrm{PA})-$ iodine and poly $(N-\mathrm{PV}-\mathrm{PA})$ against (a) E. coli and (b) $S$. aureus. Reproduced from [104] with permission from Elsevier. 
To summarize, polymer-iodine complexes are finding broad application as efficient antiseptics and antimicrobial agents in medicine, pharmacy, and environmental protection. A structural modeling of the polymeric carrier opens new possibilities to use iodophors as disinfectants and antimicrobial agents to treat conjunctival, vaginal, and oral mucosal infections.

\section{EDITORIAL STATEMENT}

The evaluation and decision of acceptance of this paper was made by the Editorial board without input of the authors or any persons affiliated with them.

\section{REFERENCES}

1. Garg, S., Jambu, L., and Vermani, K., Drug Dev. Ind. Pharm., 2007, vol. 33, no. 12, p. 1340.

2. Klimaviciute, R., Bendoraitiene, J., Rutkaite, R., Siugzdaite, J., and Zemaitaitis, A., Int. J. Biol. Macromol., 2012, vol. 51, no. 5 , p. 800.

3. Boddie, R. and Nickerson, S.C., J. Dairy Sci., 2016, vol. 80, no. 8, p. 1846.

4. Kaiho, T., Iodine Chemistry and Applications, Hoboken, NJ: Wiley, 2014.

5. Schreier, H., Erdos, G., Reimer, K., König, B., König, W., and Fleischer, W., Dermatology, 1997, vol. 195, no. 2, p. 111.

6. Blatun, L.A., Acta Biomed. Sci., 2005, vol. 41, no. 3, p. 2.

7. Courtois, B., Ann. Chim., 1813, vol. 88, p. 304.

8. Gay-Lussac, J., Ann. Chim., 1813, vol. 88, p. 311.

9. Glinka, N.L., Obshchaya khimiya (General Chemistry), Moscow: KnoRus, 2014.

10. Cooper, R.A., Int. Wound J., 2007, vol. 4, no. 2, p. 124.

11. Bendoraitiene, J., Mazoniene, E., Zemaitaitiene, R.J., and Zemaitaitis, A., J. Appl. Polym. Sci., 2006, vol. 100, no. 4, p. 2710.

12. Disinfection, Sterilization, and Preservation, Block, S.S., Ed., Philadelphia, PA: Lippincott Williams \& Wilkins, 2001.

13. Mokhnach, V.O., Iod i problemy zhizni (Teoriya biologicheskoj aktivnosti ioda i problemy prakticheskogo primeneniya soedinenij ioda s vysokopolimerami) (Iodine and the Problems of Life: The Theory of the Biological Activity of Iodine and the Problems of the Practical Use of Iodine Compounds with High Polymers), Leningrad: Nauka, 1974.

14. Awtrey, A.D. and Connick, R.E., J. Am. Chem. Soc., 1951, vol. 73, no. 4, p. 1842.

15. Gardner, J.M., Abrahamsson, M., Farnum, B.H., and Meyer, G.J., J. Am. Chem. Soc., 2009, vol. 131, no. 44, p. 16206.

16. Schulz, R.C., Fleischer, D., Henglein, A., Bossler, H.M., Trisnadi, J., and Tanaka, H., Proc. Macromolecular Microsymposia XII and XIII, Prague, 1973, p. 227.

17. Moulay, S., J. Polym. Eng., 2013, vol. 33, no. 5, p. 389.

18. Moskva, V.V., SOZH, 1996, vol. 12, p. 33.

19. Teitelbaum, R.C., Ruby, S.L., and Marks, T.J., J. Am. Chem. Soc., 1978, vol. 100, no. 10, p. 3215.

20. Choi, Y.S. and Miyasaka, K., Polym. J., 1991, vol. 23, no. 8, p. 977.

21. Heyde, M.E., Rimai, L., Kilponen, R.G., and Gill, D., J. Am. Chem. Soc., 1972, vol. 94, no. 15, p. 5222.

22. Zwick, M.M., J. Appl. Polym. Sci., 1965, vol. 9, no. 7, p. 2393.

23. Takamiya, H., Tanahashi, Y., Matsuyama, T., Tanigami, T., Yamaura, K., and Matsuzawa, S., J. Appl. Polym. Sci., 1993, vol. 50, no. 10, p. 1807.

24. Choi, Y.S. and Miyasaka, K., Polym. J., 1990, vol. 22, no. 7, p. 601.

25. Choi, Y.S. and Miyasaka, K., J. Appl. Polym. Sci., 1993, vol. 48, no. 2, p. 313.

26. Inagaki, F., Harada, I., Shimanouchi, T., and Tasumi, M., Bull. Chem. Soc. Jpn., 1972, vol. 45, no. 11, p. 3384.

27. Glikman, S.A., Tebelev, L.G., Mikul'skij, G.F., and Korchagina, E.P., Vysokomol. Soedin., 1965, vol. 7, no. 1, p. 123.

28. Yamaura, K., Shindo, N., and Matsuzawa, S., Colloid Polym. Sci., 1981, vol. 259, no. 12, p. 1143.

29. Noguchi, H., Jyodai, H., and Matsuzawa, S., Polym. Phys., 1997, vol. 35, no. 11, p. 1701.

30. Takahama, T., Saharin, S.M., and Tashiro, K., Polymer, 2016, vol. 99, p. 566.

31. Zhang, R., Soft Matter, 2009, vol. 14, no. 13, p. 2535.

32. Jayaraja, K.K., Hemanth, K.R.C., and Gunashakaran, V., J. Pharm. Sci. Technol., 2009, vol. 1, no. 2, p. 48.

33. Goodwin, M.J., Steed, B.W., Yufit, D.S., Musa, O.M., Berry, D.J., and Steed, J.W., Cryst. Growth Des., 2017, vol. 17 , no. 10 , p. 5552. 
34. Bekturov, E.A., Khamzamullina, R.E., Bakauova, Z.H., Kudaibergenov, S.E., Dzhumadilov, T.K., Cherdabaev, A.Sh., and Asaubekov, M.A., Molekulyarnye kompleksy polimerov (Molecular Complexes of Polymers), Alma-Ata: Nauka, 1988.

35. De Queiroz, A.A., de Faria, D.L., and Gil, H.A., J. Mol. Struct., 1999, vol. 479, p. 93.

36. Siggia, B.S., J. Am. Pharm. Assoc., 1956, vol. 46, no. 3, p. 201.

37. Schenck, H.U., Simak, P., and Haedicke, E., J. Pharm. Sci., 1979, vol. 68, no. 12, p. 1505.

38. Colin, G. and de Claubry, H.H., Ann. Phys., 1814, vol. 48, p. 297.

39. Wang, T.L., Bogracheva, T.Y., and Hedley, C.L., J. Exp. Bot., 1998, vol. 49, no. 320, p. 481.

40. Fan, X., Mattheis, J.U., Patterson, M.E., and Fellman, J.K., HortScience, 1995, vol. 30, no. 1, p. 104.

41. Mottiar, Y. and Altosaar, I., Trends Food Sci. Technol., 2011, vol. 22, no. 6, p. 335.

42. Hansen, C., Wayment, B., Klein, S., and Godfrey, B., Disabil. Rehabil., 2018, vol. 40, no. 25, p. 3076.

43. Bates, F.L., French, D., and Rundle, R.E., J. Am. Chem. Soc., 1943, vol. 65, no. 2, p. 142.

44. Rundle, R.E., Foster, J.F., and Baldwin, R.R., J. Am. Chem. Soc., 1944, vol. 66, no. 12, p. 2116.

45. Yu, X., Houtman, C., and Atalla, R.H., Carbohydr. Res., 1996, vol. 292, p. 129.

46. Du, X., An, H., Liu, Z., Yang, H., Wei, L., Scanning, 2014, vol. 36, no. 4, p. 394.

47. Noltemeyer, M. and Saenger, W., Nature, 1976, vol. 259, p. 629.

48. Bendoraitiene, J., Sarkinas, A., Danilovas, P.P., Rutkaite, R., Klimaviciute, R., and Zemaitaitis, A., J. Appl. Polym. Sci., 2013, vol. 128, no. 6, p. 4346.

49. Bakshi, P.S., Selvakumar, D., Kadirvelu, K., and Kumar, N.S., Int. J. Biol. Macromol., 2020, vol. 150, p. 1072.

50. Moeini, A., Pedram, P., Makvandi, P., Malinconico, M., and Gomez d'Ayala, G., Carbohydr. Polym., 2020, vol. 233, 115839.

51. Kubota, N. and Eguchi, Y., Polym. J., 1997, vol. 29, no. 2, p. 123.

52. Sogias, I.A., Khutoryanskiy, V.V., and Williams, A.C., Macromol. Chem. Phys., 2010, vol. 211, p. 426.

53. Yajima, H., Morita, M., Hashimoto, M., Sashiwa, H., Kikuchi, T., and Ishii, T., Int. J. Thermophys., 2001, vol. 22, no. 4 , p. 1265.

54. Miyajima, N., Thermochim. Acta, 2010, vol. 498, no. 1, p. 33.

55. Vlasova, O.A., Buzinova, D.A., and Fomina, V.I., Mezhvuz. sbornik nauch. trudov VIII Vseros. Konf. Molodyh uchenyh s mezhdunarodnym uchastiem (Interuniversity Collection Proc. VIII All-Russ. Conf. of Young Scientists with Int. Participation), Saratov, 2011, p. 203.

56. Tang, Y., Xie, L., Sai, M., Xu, N., and Ding, D., Mater. Sci. Eng., C, 2015, vol. 48, p. 1.

57. Tashiro, K. and Gakhutishvili, M., Polymer, 2019, vol. 171, p. 140.

58. Psimadas, D., Georgoulias, P., Valotassiou, V., and Loudos, G., J. Pharm. Sci., 2012, vol. 101, no. 7, p. 2271.

59. Wang, Y. and Easteal, A.J., J. Appl. Polym. Sci., 1999, vol. 71, no. 8, p. 1303.

60. Mizrahi, B. and Domb, A.J., J. Pharm. Sci., 2007, vol. 96, no. 11, p. 3144.

61. Sukawa, H., Polym. J., 1989, vol. 21, no. 5, p. 403.

62. Guttman, D.E. and Higuchi, T., J. Am. Pharm. Assoc. (Baltim), 1955, vol. 44, no. 11, p. 668.

63. Hemalatha, S., Chandani, B., and Balasubramanian, D., Spectrosc. Lett., 1979, vol. 12, nos. 7-8, p. 535.

64. Chang, J.H., Ohno, M., Esumi, K., and Meguro, K., J. Am. Oil Chem. Soc., 1988, vol. 65, no. 10, p. 1664.

65. Hiskey, C.F. and Cantwell, F.F., J. Pharm. Sci., 1966, vol. 55, no. 2, p. 166.

66. Ferguson, A.W., Scott, J.A., McGavigan, J., Elton, R.A., McLean, J., Schmidt, U., Kelkar, R., and Dhilon, B., Br. J. Ophthalmol., 2003, vol. 87, no. 2, p. 163.

67. Shiraishi, T., Oka, R., and Nakagawa, Y., Dermatology, 1997, vol. 2, no. 195, p. 100.

68. Kawana, R., Dermatology, 1997, vol. 2, no. 195, p. 29.

69. König, B., Reimer, K., Fleischer, W., and König, W., Dermatology, 1997, vol. 2, no. 195, p. 42.

70. Wutzler, P., Sauerbrei, A., Klöcking, R., Brögmann, B., and Reimer, K., Antiviral Res., 2002, vol. 54, no. 2, p. 89.

71. Kaplan, J.C., Crawford, D.C., Durno, A.G., and Schooley, R.T., Infect. Control, 1987, vol. 8, no. 10, p. 412.

72. Ito, H., Dermatology, 2006, vol. 212, no. 1, p. 115.

73. Poutanen, S.M., N. Engl. J. Med., 2003, vol. 348, no. 20, p. 1995.

74. Kariwa, H., Fujii, N., and Takashima, I., Dermatology, 2006, vol. 212, no. 1, p. 119.

75. Alharbi, A., Alharbi, S., and Alqaidi, S., Saudi Dent. J., 2, vol. 32, no. 4, p. 181.

76. Povidone-iodine. www.drugbank.ca/drugs/DB06812.

77. Vermeulen, H., Westerbos, S.J., and Ubbink, D.T., J. Hosp. Infect., 2010, vol. 76, no. 3, p. 191.

78. De Kock, M., der Merwe, A.E., and Swarts, C., Proc. the First Asian/Pacific Congress on Antisepsis, London, New York, 1988, p. 65.

79. Brown, R., De Wet, P.M., Rode, H., and Matley, P., Dermatology, 1997, vol. 2, no. 195, p. 195.

80. Betadine. https://betadine.com. 
81. Betadine. https://sg.betadine.com/en/sg/about-betadine-brand.

82. Recuro vaginal. www.drugs.com/otc/104778/recuro-vaginal.html.

83. Register of medicines of Russia. www.rlsnet.ru.

84. Lafferty, B., Wood, L., and Davis, P., Wounds UK, 2011, vol. 7, no. 1, p. 14.

85. Al-Kaisy, A.A. and Salih Sahib, A., Ann. Burns Fire Disasters, 2005, vol. 18, no. 1, p. 19.

86. Landsman, T.L., Touchet, T., Hasan, S.M., Smith, C., Russel, B., Rivera, J., Maitland, D.J., and CosgriffHermandez, E., Acta Biomater., 2017, vol. 47, p. 91.

87. Lundin, J.G., McGann, C.L., Weise, N.K., Estrella, L.A., Ballow, R.B., Streifel, B.C., and Wynne, J.H., React. Funct. Polym., 2019, vol. 135, no. 9, p. 44.

88. Chen, Y., Qui, H., Dong, M., Cheng, B., Jin, Y., Tong, Z., Li, P., Li, S., and Yang, Z., Carbohydr. Polym., 2019, vol. 206, p. 435.

89. Jalil, A., Matuszczak, B., Nguyen Le, N.-M., Mahmood, A., Laffleur, F., and Bernkop-Schnürch, A., Mol. Pharm., 2018, vol. 15, no. 8, p. 3527.

90. Chen, Y., Yang, Y., Liao, Q., Yang, W., Ma, W., Zhao, J., Zheng, X., Yang, Y., and Chen, R., Mater. Sci. Eng., C, 2016, vol. 67, p. 247.

91. Heiner, J.D., Hile, D.C., Demons, S.T., and Wedmore, I.S., Wilderness Environ. Med., 2010, vol. 21, no. 4, p. 332.

92. Khoerunnisa, F., Rahmah, W., Ooi, B.S., Dwihwemiati, E., Nashrah, N., Fatimah, S., Gun Ko, Y., and Ng, E.J., Environ. Chem. Eng., 2020, vol. 8, no. 2, 103686.

93. Hallouard, F., Anton, N., Choquet, P., Constantinesco, A., and Vandamme, T., Biomaterials, 2010, vol. 31, no. 24, p. 6249.

94. Kolontaeva, O.A., Khokhlova, R.A., Markina, N.E., Markin, A.V., and Burmistrova, N.A., Saratov Fall Meet. 2015 Third Int. Symp. Opt. Biophotonics Seventh Finnish-Russian Photonics Laser Symp., Saratov, 2016, p. 99171.

95. Hainfeld, J.F., Ridwan, S.M., Stanishevskiy, Y., Smilowitz, N.R., Davis, J., and Smilowitz, H.M., Sci. Rep., 2018, vol. 8, no. 1, p. 2.

96. Limchoowong, N., Sricharoen, P., Techawongstien, S., and Chanthai, S., Food Chem., 2016, vol. 200, p. 223.

97. Koerner, J.C., George, M.J., Meyer, D.R., Rosco, M.G., and Habib, M.M., Surv. Ophthalmol., 2018, vol. 63, no. 6, p. 862 .

98. Zakut, H., Lotan, M., and Bracha, Y., Clin. Exp. Obstet. Gynecol., 1987, vol. 14, no. 1, p. 1.

99. Khutoryanskiy, V.V., Macromol. Biosci., 2011, vol. 11, no. 6, p. 748.

100. Asim, M.H., Moghadam, A., Ijaz, M., Mahmood, A., Gotz, R.X., Matuszczak, B., and Bernkop-Schnurch, A., $J$. Colloid Interface Sci., 2018, vol. 531, p. 261.

101. Moghadam, A., Ijaz, M., Asim, M.H., Mahmood, A., Jelkmann, M., Matuszczak, B., and Bernkop-Schnurch, A., Int. J. Nanomed., 2018, vol. 13, p. 4003.

102. Li, J. and Loh, X.J., Adv. Drug Delivery Rev., 2008, vol. 60, no. 9, p. 1000.

103. Munaf, E., Takeuchi, T., and Miwa, T., Anal. Chim. Acta, 2000, vol. 418, no. 2, p. 175.

104. US Patent 6521243B2.

105. Pawar, V., Topkar, H., and Srivastava, R., Int. J. Biol. Macromol., 2018, vol. 115, p. 1131.

106. Qi, L., Xu, Z., Jiang, X., Hu, C., and Zou, X., Carbohydr. Res., 2004, vol. 339, no. 16, p. 2693.

107. Summa, M., Russo, D., Penna, I., Margaroli, N., Bayer, I.S., Bandiera, T., Athanassiou, A., and Bertorelli, R., Eur. J. Pharm. Biopharm., 2018, vol. 122, p. 17.

108. Sai, M., Guo, R., Chen, L., Xu, N., Tang, Y., and Ding, D., J. Appl. Polym. Sci., 2015, vol. 132, no. 14, p. 41797. 109. Xu, N. and Ding, D., R. Soc. Chem. Adv., 2015, vol. 5, no. 97, p. 79820.

110. Saiki, Y., Nippon Gomu Kyokaishi, 2011, vol. 84, no. 8, p. 237.

111. Land, E.H., J. Opt. Soc. Am., 1951, vol. 41, no. 12, p. 957.

112. Borjihan, Q., Yang, J., Zhang, Z., Zi, X., Huang, M., Che, Y., and Dong, A., J. Hazard. Mater., 2020, vol. 384, 121305.

113. Zhang, W., Li, Q., Mao, Q., and He, G., Carbohydr. Polym., 2019, vol. 209, no. 9, p. 215.

114. Li, Q., Mao, Q., Li, M., Zhang, S., He, G., and Zhang, W., Carbohydr. Polym., 2020, vol. 234, no. 1, 115926.

Translated by T. Tkacheva 